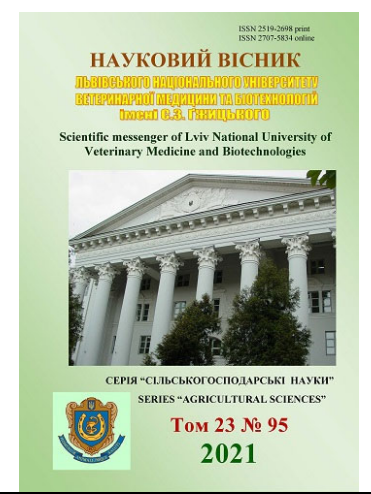

Науковий вісник Дьвівського національного університету ветеринарної медицини та біотехнологій імені С.3. Гжицького. Серія: Сільськогосподарські науки

\author{
Scientific Messenger of Lviv National University \\ of Veterinary Medicine and Biotechnologies. \\ Series: Agricultural sciences
}

doi: 10.32718/nvlvet-a9523

https://nvlvet.com.ua/index.php/agriculture

UDC 636.4:087.7:612.015.3

\title{
The level of products of lipid peroxidation in the blood of piglets at the action feed additive "Sylimevit"
}

L. V. Vyslotska ${ }^{1}$, B. V. Gutyj ${ }^{1}$, V. I. Khalak ${ }^{2}$, T. V. Martyshuk ${ }^{1}$, V. B. Todoriuk ${ }^{1}$, O. I. Stadnytska ${ }^{3}$, N. V. Magrelo ${ }^{1}$, H. V. Sus ${ }^{1}$, A. O. Vysotskyi ${ }^{1}$, U. M. Vus ${ }^{1}$, V. R. Magrelo ${ }^{1}$

${ }^{1}$ Stepan Gzhytskyi National University of Veterinary Medicine and Biotechnologies Lviv, Ukraine

${ }^{2}$ State Institution Institute of Grain Crops of NAAS of Ukraine, Dnipro, Ukraine

${ }^{3}$ Institute of Agriculture of the Carpathian region of NAAS of Ukraine, v. Obroshino, Lviv region, Ukraine

\section{Article info}

Received 05.07.2021

Received in revised form 09.08 .2021

Accepted 10.08.2021

Stepan Gzhytskyi National University of Veterinary Medicine and Biotechnologies Lviv, Pekarska Str., 50, Lviv, 79010, Ukraine. Tel.: +38-068-136-20-54 E-mail:bvh@ukr.net

State Institution Institute of grain crops of NAAS, V. Vernadsky Str., 14, Dnipro, 49027, Ukraine. Tel.: +38-067-892-44-04 E-mail:v16kh91@gmail.com

Institute of Agriculture of the Carpathian region of the National Academy of Agrarian Sciences of Ukraine Grushevskogo Str. 5, Obroshino, Pustomytovsky District, Lviv Region, 81115, Ukraine.
Vyslotska, L. V., Gutyj, B. V., Khalak, V. I., Martyshuk, T. V., Todoriuk, V. B., Stadnytska, O. I., Magrelo, N. V., Sus, H. V., Vysotskyi, A. O., Vus, U. M., \& Magrelo, V. R. (2021). The level of products of lipid peroxidation in the blood of piglets at the action feed additive "Sylimevit". Scientific Messenger of Lviv National University of Veterinary Medicine and Biotechnologies. Series: Agricultural sciences, 23(95), 154-159. doi: 10.32718/nvlvet-a9523

Intensive pig breeding has been reported in the literature to suggest that early weaning of piglets from sows is an extreme stimulus that reduces the protective and adaptive responses of piglets. That is why the aim of the study was to study the effect of the feed additive "Sylimevit" on the level of lipid peroxidation products of piglets after weaning. Two groups of piglets were formed - control and experimental in the amount of 10 individuals in each group, selected on the principle of analogs - age, breed and body weight. During the weaning period, the piglets were kept under the sow in special machines, had constant access to the mother, and from the age of 5 days - free access to concentrated feed. While feeding of animals was carried out in accordance with the norms for a given age of pigs. Prior to the study, a clinical and physiological examination of the piglets was performed. Their general condition and activity when eating food were taken into account. On the 28th day of life, the piglets were weaned from the sow and regrouped from different nests in order to be further maintained during the period of fattening and rearing with a change in the structure of the diet, which served as technological stress for the animals. From the age of 5 days, piglets of all groups were fed pre-starter feed. Piglets of the experimental group, from 21 to 40 days of age, were additionally fed the feed supplement "Sylimevit" at a dose of $100 \mathrm{mg} / \mathrm{kg}$ body weight per day. The technological stress of weaning piglets from sows is accompanied by a gradual probable intensification of lipid peroxidation processes. Feeding Sylimevit feed to piglets after weaning helped to reduce the content of intermediate and final products of lipid peroxidation: lipid hydroperoxides - by $52 \%(P<0.001)$ and TBAactive products - by $22.5 \%(P<0.01)$. Thus, feeding the piglets of the experimental group of the feed additive "Sylimevit" helped to suppress the processes of lipid peroxidation in animals. Thus, the results of the use of feed additive "Sylimevit" in weaned piglets showed a pronounced antioxidant effect. The components of the feed additive directly interacted with reactive oxygen species and free radicals, preventing the development of oxidative stress.

Key words: oxidative stress, vitamins, milk thistle, matifen, blood, lipid peroxidation.

\section{Рівень продуктів пероксидного окиснення ліпідів у крові поросят за дії кормової добавки "Силімевіт"}

\author{
Л. В. Вислоцька ${ }^{1}$, Б. В. Гутий ${ }^{1}$, В. І. Халак ${ }^{2}$ Т. В. Мартишук ${ }^{1}$, В. Б. Тодорюк ${ }^{1}$, О. І. Садницька ${ }^{3}$, \\ Н. В. Магрело ${ }^{1}$, Г. В. Сус ${ }^{1}$, А. О. Висоцький ${ }^{1}$, У. М. Вус ${ }^{1}$, В. Р. Магрело ${ }^{1}$
}

${ }^{1}$ Львівський національний університет ветеринарної медицини та біотехнологій імені С. 3. Гэицького, м. Львів, Украӥна 
${ }^{2}$ Державна установа “Інститут зернових культур НААН України”, м. Дніпро, Україна ${ }^{3}$ Інститут сільського господарства Карпатського регіону НААН Украӥни, с. Оброшине, Львівська область, Україна

При інтенсивному веденні свинарства з повідомлень в літературі відомо, шчо раннє відлучення поросят від свиноматок є екстремальним подразником, який спричиняє зниження захисно-пристосувальних реакцій організму поросят. Саме тому метою проведених досліджень було вивчити вплив кормової добавки “Силімевіт” на рівень продуктів пероксидного окиснення ліпідів організму поросят після відлучення. Було сформовано дві групи поросят - контрольну і дослідну в кількості 10 особин у кожній групі, підібраних за принципом аналогів - віком, породою і масою тіла. У підсисний період поросята утримувалися під свиноматкою у спеціальних станках, мали постійний доступ до матері, а з 5-добового віку - вільний доступ до концентрованих кормів. Годівля тварин проводилась відповідно до норм для даного віку свиней. Перед проведенням досліджень здійснювали клінічно-фізіологічне обстеження поголів'я поросят. Враховували їхній загальний стан та активність при поїданні корму. На 28 добу життя поросят відлучали від свиноматки та перегруповували з різних гнізд з метою подальшого утримання у період відгодівлі та дорощування зі зміною структури раціону, щуо слугувало технологічним стресом для організму тварин. Починаючи з 5-добового віку поросят усіх груп підгодовували престартерним комбікормом. Поросятам дослідної групи, починаючи з 21- до 40-добового віку, додатково згодовували кормову добавку “Силімевіт” у дозі 100 мг/кг маси тіла на добу. Технологічний стрес відлучення поросят від свиноматок супроводжується поетапним вірогідним посиленням процесів пероксидного окиснення ліпідів. Згодовування кормової добавки “Силімевіт” поросятам після відлучення сприяло зниженню вмісту проміжних і кінцевих продуктів пероксидного окиснення ліпідів: гідроперекисів ліпідів - на $52 \%$ (P<0,001) і ТБК-активних продуктів - на 22,5\% (P<0,01). Отже, згодовування поросятам дослідної групи кормової добавки “Силімевіт” сприяло пригніченню процесів пероксидного окиснення ліпідів в організмі тварин. Таким чином, результати застосування кормової добавки “Силімевіт” поросятам при відлученні показали виражену антиоксидантну дію. Складники кормової добавки безпосередньо взаємодіяли з активними формами кисню та вільними радикалами, запобігаючи розвитку оксидаційного стресу.

Ключові слова: оксидаційний стрес, вітаміни, розторопша плямиста, метіфен, кров, пероксидне окиснення ліпідів.

\section{Вступ}

Підвищення збереження та життєздатності новонароджених тварин в умовах промислового вирощування належить до найбільш актуальних науковопрактичних проблем сучасного тваринництва (Hedemann \& Jensen, 2004; Bulter et al., 2006; ArizaNieto et al., 2011; Han et al., 2019; Khalak \& Gutyj, 2020; Khalak et al., 2020; 2021). Впровадження інтенсивних технологій у свинарстві передбачає раннє відлучення поросят від свиноматок, що призводить до виникнення так званих технологічних стресів, що в подальшому викликає порушення їхнього метаболічного гомеостазу і посилення в організмі процесів пероксидного окиснення ліпідів (De Lange et al., 2010; Gutyj et al., 2017; Czech et al., 2018). Водночас важливо зазначити, що розвиток оксидаційного стресу у поросят супроводжується активацією вільнорадикального окиснення ліпідів плазматичних і внутрішньоклітинних мембран гепатоцитів на тлі виснаження захисних протирадикальних систем (Frankic et al., 2010; Heo et al., 2012). Активація процесів пероксидного окиснення ліпідів та утворення великої кількості вільних радикалів призводить не тільки до пошкодження гепатоцитів, а й до змін у клітинах крові найбільш мобільній системі організму (Jacela et al., 2010; Ivankiv et al., 2019).

Вільнорадикальне окиснення являє собою процес безпосереднього перенесення оксигену на субстрат 3 подальшим утворенням перекисів, альдегідів, тощо (Ahmad et al., 2011). Це один із універсальних механізмів, який дозволяє контролювати цілісність, вибіркову проникність та в'язкість клітинних мембран (Varkholiak et al., 2021; Gutyj et al., 2021). Постійна наявність в організмі вільних радикалів $є$ необхідною складовою при транспортуванні електронів у дихальному ланцюзі, індукції утворення пор у мітохондріальних мембранах тощо. Таким чином, процеси окиснення за участі активованих кисневих метаболітів виконують функції міжклітинних та внутрішньоклітинних месенджерів, модуляторів та індукторів у біохімічній регуляції і реалізації метаболічних процесів (Khariv et al., 2016; 2017).

Вільно-радикальне пероксидне окиснення практично на всіх етапах свого перебігу утворює ряд продуктів, які є результатом взаємодії вільних радикалів як між собою, так і з біологічними макромолекулами (Lavryshyn et al., 2016; Studenok et al., 2021). Так, при ВРПО разом 3 активними формами кисню (АФК) утворюються й інші активні радикали (пероксиди, епоксиди, альдегіди, кетони, спирти, діальдегіди та ін.), які здатні ковалентно взаємодіяти 3 окремими функціональними групами білків, що приводить до їх полімеризації і руйнування амінокислотних залишків, особливо тих, які містять SH-, SCH3-групи цистеїну, метіоніну, NH-групи лізину тощо. Усе це може викликати модифікацію білків, у тому числі ензимів, зміну їхньої активності, руйнування біоантиокиснювачів (вітамінів, убіхінону, стероїдних гормонів тощо), зміну фосфоліпідного складу, появу в гідрофобній частині продуктів окиснення, які ініціюють процеси іонного транспорту, зміну конформації білків і ліпідного складу, а звідси - структурних і функціональних властивостей мембран (Martyshuk et al., 2016; 2019; 2020; 2021).

Для зменшення негативної дії технологічного стресу у поросят розробляють та впроваджують ефективні та економічно вигідні засоби (Kramarenko et al., 2018; 2019). Особливо перспективним у даному напрямі $є$ використання кормових добавок на основі рослинної сировини. $Є$ окремі повідомлення про стимулюючий вплив розторопші плямистої, метіфену, Селену та вітамінів на активність антиоксидантної та гепатопротекторної дії у поросят (Martyshuk \& Hutyi, 2021). Однак комплексне застосування вказаних речовин у складі кормової добавки “Силімевіт” на антиоксидантний статус організму відлучених поросят на 
даний час у науковій літературі висвітлене недостатньо.

Саме тому метою проведених досліджень було вивчити вплив кормової добавки "Силімевіт" на рівень продуктів пероксидного окиснення ліпідів організму поросят після відлучення.

\section{Матеріал і методи досліджень}

Досліди проводились на базі ТОВ “КОШЕТ” Мукачівського району Закарпатської області. Було сформовано дві групи поросят - контрольну (К) і дослідну (Д) в кількості 10 особин у кожній групі, підібраних за принципом аналогів - віком, породою і масою тіла. У підсисний період поросята утримувалися під свиноматкою у спеціальних станках, мали постійний доступ до матері, а з 5-добового віку - вільний доступ до концентрованих кормів. Годівля тварин проводилась відповідно до норм для даного віку свиней. Перед проведенням досліджень здійснювали клінічнофізіологічне обстеження поголів'я поросят, враховували їхній загальний стан та активність при поїданні корму. На 28 добу життя поросят відлучали від свиноматки та перегруповували 3 різних гнізд з метою подальшого утримання у період відгодівлі та дорощування зі зміною структури раціону, що слугувало технологічним стресом для організму тварин. Починаючи з 5-добового віку поросят усіх груп підгодовували престартерним комбікормом. Поросятам дослідної групи, починаючи з 21- до 40-добового віку додатково згодовували кормову добавку “Силімевіт” у дозі 100 мг/кг маси тіла на добу.

Матеріалом для досліджень була кров, яку відбирали вранці, до годівлі тварин шляхом пункції краніальної порожнистої вени на 20 добу життя (період до відлучення), на 25 добу життя (період до відлучення), на 30 добу життя (2 доба після відлучення), на 35 добу життя (7 доба після відлучення), на 40 добу життя (12 доба після відлучення).

Вміст гідропероксидів ліпідів (ГПЛ) у плазмі крові визначали за реакцією з тіоціанатом амонію за методом В.В. Мирончика (1998). Вміст ТБК-активних продуктів - за методом Е. Н. Коробейникова (1989).

Експериментальні дослідження проводили відповідно до Закону України "Про захист тварин від жорстокого поводження" від 28.03.2006 р. та правил Свропейської конвенції захисту хребетних тварин, які використовуються в експериментальних та інших наукових цілях, від 13.11.1987 р.

Аналіз результатів досліджень проводили за допомогою пакету програм Statistica 6.0. Вірогідність різниць оцінювали за t-критерієм Стьюдента. Результати середніх значень вважали статистично вірогідними при * - Р<0,05, ** - P $<0,01, * * *$ - $<<0,001$ (ANOVA).

\section{Результати та їх обговорення}

Відомо, що проміжним етапом окиснення наявних у ліпідах поліненасичених жирних кислот пероксидним шляхом $\epsilon$ утворення гідроперекисів ліпідів, 3 якими значною мірою пов'язана деструктивна дія продуктів ПОЛ у клітині. Згідно $з$ проведеними дослідженнями встановлено, що на 20-у добу досліду рівень гідроперекисів ліпідів коливався у межах $0,48 \pm 0,016-0,49 \pm 0,013$ ОЕ/мл. На 25-у добу досліду рівень проміжних продуктів ПОЛ у крові поросят контрольної групи зріс на 41,7 \%, а у дослідної групи - на 16,3 \% щодо початкових величин. У 30-добових поросят контрольної та дослідної груп встановлено зниження рівня гідроперекисів ліпідів у їхній крові. Найнижчий рівень проміжних продуктів був у крові дослідної групи поросят, де порівняно 3 контролем він знизився на $20,8 \%$.

На 35-у добу досліду встановлено зростання рівня гідроперекисів ліпідів у крові поросят контрольної групи, тимчасом як у крові дослідної групи даний показник знижувався.

Вірогідне зниження досліджуваного показника у крові дослідних поросят спостерігали з 35-ї доби досліду, де порівняно 3 контрольною групою поросят рівень гідроперекисів ліпідів знизився на 40,6 \%, а на 40 добу - на 52 \% відповідно.

При дослідженні рівня кінцевих продуктів ПОЛ встановлено зростання рівня ТБК-активних продуктів у крові поросят контрольної групи на 13,7 \%, а у дослідної групи - на 1,8 \% стосовно початкових величин.

При згодовуванні кормової добавки "Силімевіт" поросятам дослідної групи після відлучення встановлено зниження рівня ТБК-активних продуктів у їхній крові протягом усього досліду. Так, на 30-у добу досліду рівень кінцевих продуктів ПОЛ у крові поросят дослідної групи вірогідно знизився на 15,6 \% щодо контрольної групи. На 35- і 40-у доби досліду рівень ТБК-активних продуктів у крові дослідної групи поросят був найнижчим і порівняно з контрольною групою він знизився на 23 і 22,5 \% відповідно.

Отже, згодовування поросятам дослідної групи кормової добавки “Силімевіт" сприяло пригніченню процесів пероксидного окиснення ліпідів в організмі тварин та запобіганню розвитку оксидаційного стресу.

Таким чином, результати застосування кормової добавки "Силімевіт" поросятам при відлученні показали виражену антиоксидантну дію. Складники кормової добавки безпосередньо взаємодіяли 3 активними формами кисню та вільними радикалами, запобігаючи розвитку оксидаційного стресу. Варто також зазначити, що складники кормової добавки діють як синергісти і тому вони більше пригнічували процеси пероксидного окиснення ліпідів. Застосування кормової добавки "Силімевіт" поросятам за умов розвитку оксидаційного стресу сприяло потрійному захисту клітини від дії агресивних вільних радикалів, а саме: подвійному захисту мембрани клітини як із зовнішнього, так і з внутрішнього боку та захисту всередині клітини. 


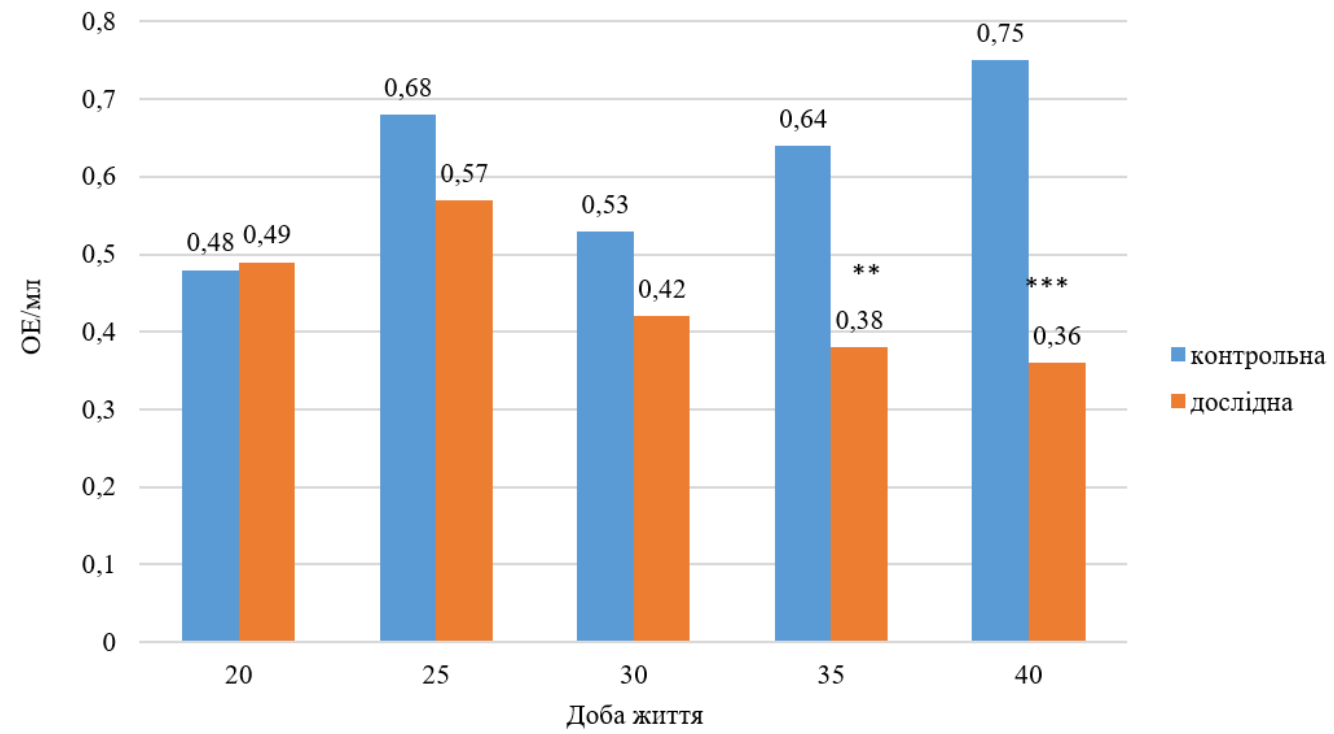

Рис. 1. Вміст гідроперекисів ліпідів у крові поросят за дії кормової добавки “Силімевіт”

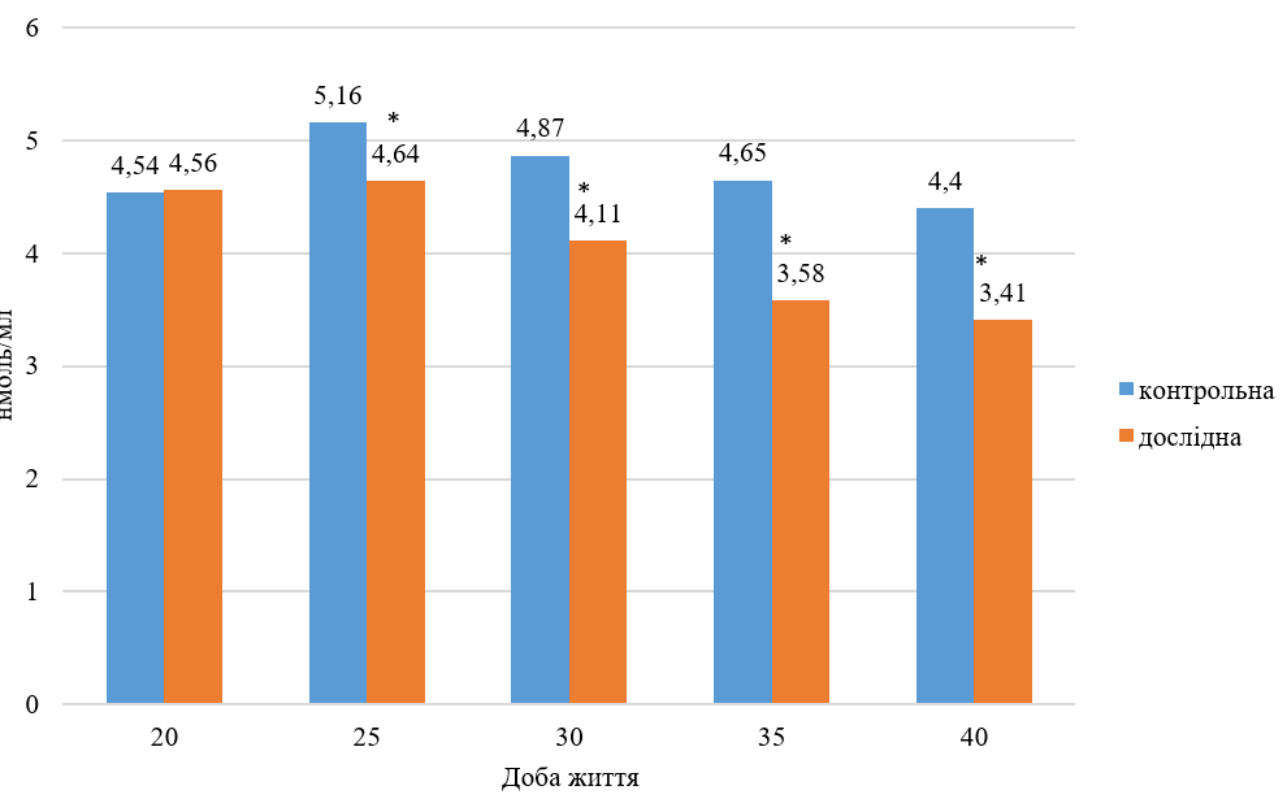

Рис. 2. Вміст ТБК-активних продуктів у крові поросят за дії кормової добавки “Силімевіт”

Наші дослідження підтвердили дані інших авторів про те, що вітаміни, а також розторопша плямиста здатні безпосередньо діяти як антиоксиданти, а саме: бути донорами електронів для вільних радикалів, перетворюючи останні на молекулярні речовини, обриваючи цим самим ланцюг вільнорадикальних реакцій і знижуючи в організмі тварин кількість продуктів ПОЛ та окисної модифікації протеїнів (Stojanovskyj \& Ogrodnyk, 2016; Sobolev et al., 2017).

\section{Висновки}

Технологічний стрес відлучення поросят від свиноматок супроводжується поетапним вірогідним посиленням процесів пероксидного окиснення ліпідів.

Згодовування кормової добавки "Силімевіт" поросятам після відлучення сприяло зниженню вмісту проміжних і кінцевих продуктів пероксидного окиснення ліпідів: гідроперекисів ліпідів - на $52 \%(\mathrm{P}<0,001)$ i ТБК-активних продуктів - на 22,5 \% (P<0,01).

Перспективи подальших досліджень. У подальшому планується дослідження впливу кормової добавки "Силімевіт" на імунний статус організму поросят при відлученні.

\section{References}

Ahmad, M. K., Amani, S., \& Mahmood, R. (2011). Potassium bromate causes cell lysis and induces oxidative stress in humanerythrocytes. Environmental Toxicology, 29(2), 138-145. doi: 10.1002/tox.20780.

Ariza-Nieto, C., Bandrick, M., Baidoo, S. K., Molitor, T. W., \& Hathaway, M. R. (2011). Effect of dietary supplementation of oregano essential oils to sows on colostrum and milk composi-tion, growth pattern and im- 
mune status of suckling pigs. Journal of Animal Science, 89(4), 1079-1089. doi: 10.2527/jas.2010-3514.

Bulter, J., Sinkora, M., \& Wertz, N. (2006). Development of the neonatal $\mathrm{B}$ and $\mathrm{T}$ cell repertoire in swine: implications for com-parative and veterinary immunology. Veterinary Research, 37(3), 417-441. doi: 10.1051/vetres:2006009.

Czech, A., Smolczyk, A., \& Ognik, K. (2018). Effect of dietary supplementation with Yarrowia lipolytica or Saccharomyces cerevisiae yeast and probiotic additives on haematological parameters and the gut microbiota in piglets. Research in Veterinary Science, 119, 221-227. doi: 10.1016/j.rvsc.2018.06.007.

De Lange, C., Pluske, J. R., Gong, J., \& Nyachoti, C. M. (2010). Strategic use of feed ingredients and feed additives to stimulate gut health and development in young pigs. Livestock Science, 134(1-3), 124-134. doi: 10.1016/j.livsci.2010.06.117.

Frankic, T., Levart, A., \& Salobir, J. (2010). The effect of vitamin $\mathrm{E}$ and plant extract mixture composed of carvacrol, cinnamalde-hyde and capsaicin on oxidative stress induced by high PUFA load in young pigs. Animal, 4(4), 572-578. doi: 10.1017/S1751731109991339.

Gutyj, B., Leskiv, K., Shcherbatyy, A., Pritsak, V., Fedorovych, V., Fedorovych, O., Rusyn, V., \& Kolomiiets, I. (2017). The influence of Metisevit on biochemical and morphological indicators of blood of piglets under nitrate loading. Regulatory Mechanisms in Biosystems, 8(3), 427-432. doi: 10.15421/021766.

Gutyj, B., Martyshchuk, T., Bushueva, I., Semeniv, B., Parchenko, V., Kaplaushenko, A., Magrelo, N., Hirkovyy, A., Musiy, L., \& Murska, S. (2017). Morphological and biochemical indicators of blood of rats poisoned by carbon tetrachloride and subject to action of liposomal preparation. Regulatory Mechanisms in Biosystems, 8(2), 304-309. doi: 10.15421/021748.

Gutyj, B., Khariv, I., Khalak, V., Khariv, M., Vasiv, R., Leskiv, Kh., Martyshuk, T., \& Guta, Z. (2021). The effect of liposomal drug "Butaintervit" on the activity of the t-system of cellular immunity of rats under oxidative stress. Colloquium-journal, 22(109), 14-18. doi: 10.24412/2520-6990-2021-22109-14-18.

Han, C., Dai,Y., Liu, B. Wang, L., Wang, J., \& Zhang, J. (2019). Diversity analysis of intestinal microflora between healthy and diarrheal neonatal piglets from the same litter in different re-gions. Anaerobe, 55, 136141. doi: 10.1016/j.anaerobe.2018.12.001.

Hedemann, M. S., \& Jensen, B. B. (2004). Variations in enzyme activity in stomach and pancreatic tissue and digesta in piglets around weaning. Archives of Animal Nutrition, 58(1), 47-59. doi: 10.1080/00039420310001656677.

Heo, J. M., Opapeju, F. O., \& Kim, J. C. (2012). Gastrointestinal health and function in weaned pigs: a review of feeding strate-gies to control post-weaning diarrhoea without using in-feed an-timicrobial compounds. Journal of Animal Physiology and Ani-mal Nutrition, 97(2), 207-237. doi: 10.1111/j.1439-0396.2012.01284.x.

Ivankiv, M., Kachmar, N., Mazurak, O., \& Martyshuk, T. (2019). Hepatic protein synthesis and morphological parameters in blood of rats under oxidative stress and action of feed additive "Bu-taselmevit-plus". Ukrainian Journal of Ecology, 9(4), 628-633. URL: https://www.ujecology.com/abstract/hepatic-protein- synthesis-and-morphological-parameters-in-blood-ofrats-under-oxidative-stress-and-action-of-feed-additi44975.html.

Jacela, J. Y., DeRouchey, J. M., \& Tokach, M. D. (2010). Feed additives for swine: Fact sheets - prebiotics and probiotics, and phytogenics. Kansas Agricultural Experiment Station Research Reports, 18(3), 132-136. doi: 10.4148/2378-5977.7067.

Khalak, V., \& Gutyj, B. (2020). Physicochemical properties and chemical composition of muscle tissue of young pigs of large white breed and their correlation with some serum enzymes. Ukrainian Journal of Veterinary and Agricultural Sciences, 3(3), 34-38. doi: 10.32718/ujvas3-3.07.

Khalak, V., Dudchak, I., Gutyj, B., Stadnytska, O., Vakulik, V., Pundiak, T., Zmiia, M., Slepokura, O., Bordun, O., Smyslov, S. (2021). Some biochemical indicators of serum, fattening, and meat quality of young pigs of different classes of distribution according to the Sazer-Fredin index. Ukrainian Journal of Ecology, 11(7), 6-13. doi: 10.15421/2021_236

Khalak, V., Gutyj, B., Stadnytska, O., Shuvar, I., Balkovskyi, V., Korpita, H., Shuvar, A., Bordun, O. (2021). Breeding value and productivity of sows of the Large White breed. Ukrainian Journal of Ecology, 11(1), 319-324. doi: 10.15421/2021 48.

Khalak, V., Gutyj, B., Bordun, O., Ilchenko, M., \& Horchanok, A. (2020). Effect of blood serum enzymes on meat qualities of piglet productivity. Ukrainian Journal of Ecology, 10(1), 158-161. doi: 10.15421/2020_25.

Khalak, V., Gutyj, B., Bordun, O., Horchanok, A., Ilchenko, M., Smyslov, S., Kuzmenko, O., \& Lytvyshchenko, L. (2020). De-velopment and reproductive qualities of sows of different breeds: innovative and traditional methods of assessment. Ukrainian Journal of Ecology, 10(2), 356-360. doi: 10.15421/2020_109.

Khariv, M., Gutyj, B., Butsyak, V., \& Khariv, I. (2016). Hematological indices of rat organisms under conditions of oxidative stress and liposomal preparation action. Biological Bulletin of Bogdan Chmelnitskiy Melitopol State Pedagogical University, 6(1), 276-289. doi: $10.15421 / 201615$.

Khariv, M., Gutyj, B., Ohorodnyk, N., Vishchur, O., Khariv, I., Solovodzinska, I., Mudrak, D., Grymak, C., \& Bodnar, P. (2017). Activity of the T- and B-system of the cell immunity of animals under conditions of oxidation stress and effects of the liposomal drug. Ukrainian Journal of Ecology, 7(4), 536-541. doi: 10.15421/2017 157.

Kramarenko, S. S., Lugovoy, S. I., Kharzinova, V. R., Lykhach, V., Kramarenko, A. S., \& Lykhach, A. V. (2018). Genetic diversity of Ukrainian local pig breeds based on microsatellite markers. Regulatory Mechanisms in Biosystems, 9(2), 177-182. doi: 10.15421/021826.

Kramarenko, S., Lugovoy, S., Lykhach, A., Kramarenko, A., \& Lykhach, V. (2018). A comparative study of the reproductive traits and clustering analysis among different pig breeds. Scien-tific Messenger of LNU of Veterinary Medicine and Biotechnol-ogies. Series: Agricultural Sciences, 20(84), 21-26. doi: 10.15421/nvlvet8404.

Kramarenko, S., Lugovoy, S., Lykhach, A., Kramarenko, A., Lykhach, V., \& Slobodianyk, A. (2019). Effect of genet- 
ic and non-genetic factors on the reproduction traits in Ukrainian Meat sows. Scientific Messenger of LNU of Veterinary Medicine and Biotechnologies. Series: Agricultural Sciences, 21(90), 3-8. doi: 10.32718/nvlveta9001.

Lavryshyn, Y. Y., Varkholyak, I. S., Martyschuk, T. V., Guta, Z. A., Ivankiv, L. B., Paladischuk, O. R., Murska, S. D., Gutyj, B. V., \& Gufriy, D. F. (2016). The biological significance of the antioxidant defense system of animals body. Scientific Messenger LNUVMBT named after S.Z. Gzhytskyj, 18(2(66)), 100-111. doi: 10.15421/nvlvet6622.

Martyshuk, T.V., Gutyj, B.V., \& Vishchur, O.I. (2016). Level of lipid peroxidation products in the blood of rats under the influence of oxidative stress and under the action of liposomal preparation of " $\mathrm{Bu}$ taselmevit'. Biological Bulletin of Bogdan Chmelnitskiy Melitopol State Pedagogical University, 6(2), 22-27. doi: 10.15421/201631.

Martyshuk, T. V., Gutyj, B. V., Vishchur, O. I., \& Todoriuk, V. B. (2019). Biochemical indices of piglets blood under the action of feed additive "Butaselmevitplus". Ukrainian Journal of Veterinary and Agricultural Sciences, 2(2), 27-30. doi: 10.32718/ujvas2-2.06.

Martyshuk T. V., Gutyj B. V., Vishchur O. I. (2019). Morphological and biochemical indices of piglets' blood by the action of feed additive "Butaselmevitplus". The Animal biology, 21(4), 65-70. doi: 10.15407/animbiol21.04.065.

Martyshuk, T. V., Gutyj, B. V., Zhelavskyi, M. M., Midyk. S. V., Fedorchenko, A. M., Todoriuk, V. B., Nahirniak, T. B., Kisera, Ya. V., Sus, H. V., Chemerys, V. A., Levkivska, N. D., \& Iglitskej, I. I. (2020). Effect of Butaselmevit-Plus on the immune system of piglets during and after weaning. Ukrainian Journal of Ecology, 10(2), 347-352. doi: 10.15421/2020_106

Martyshuk, T. V., Gutyj, B. V., Leskiv, Kh. Y̌a., Semaniuk, N. V., \& Shnaider, V. L. (2021). The effect of the liposomal drug "butaselmevit" on the enzymatic and non-enzymatic part of the glutatoin system of the blood of rats under oxidative stress. Colloquiumjournal, 12(99), 16-19.
Martyshuk, T., Gutyj, B., \& Khalak, V. (2021). System of antioxidant protection of the body of piglets under the action of feed additive "Butaselmevit-plus". Ukrainian Journal of Veterinary and Agricultural Sciences, 4(2), 38-43. doi: 10.32718/ujvas4-2.07.

Martyshuk, T. V., \& Hutyi, B. V. (2021). Imunofiziolohichnyi stan ta antyoksydantnyi potentsial orhanizmu porosiat za umov oksydatsiinoho stresu ta dii koryhuiuchykh chynnykiv: monohrafiia. Lviv: SPOLOM (in Ukrainian).

Ostapyuk, A.Y., Holubieva, T.A., Gutyj, B.V., \& Slobodian, S.O. (2021). The effect of sylimevit, metifen, and milk thistle on the intensity of the processes of peroxidation of lipids in the body of laying hens in experimental chronic cadmium toxicosis. Ukrainian Journal of Ecology, 11(4), 57-63. doi: 10.15421/2021_199.

Sobolev, A., Gutyj, B., Grynevych, N., Bilkevych, V., \& Mashkin, Y. (2017). Enrichment of meat products with selenium by its introduction to mixed feed compounds for birds. Regulatory Mechanisms in Biosystems, 8(3), 417-422. doi: 10.15421/021764.

Stojanovskyj, V., \& Ogrodnyk, M. (2016). Function of intestinal immune barrier of piglets under technological stress. Scientific Messenger of LNU of Veterinary Medicine and Biotechnologies. Series: Veterinary Sciences, 18(3(71), 112-116. doi: 10.15421/nvlvet7126.

Studenok, A. A., Shnurenko, E. O., Karpovskyi, V. I., Trokoz, V. O. \& Gutyj, B. V. (2021). Indicators of protein metabolism and intensity of lipid peroxide oxidation in chickens with different vegetative status. Scientific Messenger of Lviv National University of Veterinary Medicine and Biotechnologies. Series: Veterinary sciences, 23(102), 110-118. doi: 10.32718/nvlvet10217.

Varkholiak, I.S., Gutyj, B.V., Leskiv, Kh.Ya., Kushnir, V.I., Hariv, I. I., Martyshuk, T. V., \& Guta Z. A. (2021). The effect of bendamine on antioxidant protection of rats' myocardium in doxorubicin intoxication. Colloquium-journal, 7(94), 18-21. doi: 10.24412/2520-6990-2021-794-18-21. 